\title{
CONF-950801-20
}

Contribution to American Chemical Society National Meeting, Chicago, IL, August 20-24, 1995, Division of Nuclear Chemistry and Technology, Symposium on Applications of Synchrotron Radiation in Chemistry and Related Fields

\section{EXAFS STUDIES OF LANTHANIDE COORDINATION IN CRYSTALLINE PHOSPHATES AND AMORPHOUS PHYTATES}

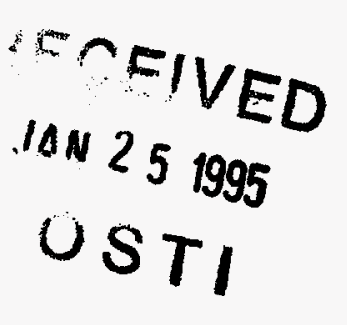

\author{
Lester R. Morss, ${ }^{1}$ Mark A. J. Schmidt, ${ }^{1}$ Kenneth L. Nash, ${ }^{1}$ Patrick G. \\ Allen, ${ }^{2}$ Jerome J. Bucher, ${ }^{2}$ Norman Edelstein, ${ }^{2}$ David K. Shuh, ${ }^{2}$ Melissa A. \\ Denecke, ${ }^{3}$ Heino Nitsche, ${ }^{3}$ and Tobias Reich ${ }^{3}$ \\ ${ }^{1}$ Chemistry Division, Argonne National Laboratory, Argonne, IL 60439 \\ 2Lawrence Berkeley National Laboratory, Berkeley, CA 94720 \\ ${ }^{3}$ Institut für Radiochemie, Forschungszentrum Rossendorf, Postfach \\ 510119, D-01314 Dresden, Federal Republic of Germany
}

\section{INTRODUCTION}

As part of the Efficient Separations and Processing Integrated Program of the U.S. Department of Energy, technologies are being developed that can stabilize radioactive and hazardous contaminants in order to reduce their potential to migrate from buried waste matrices. This report is part of a study to immobilize actinide ions in the near-surface environment by reacting them with organophosphorus complexants that decompose to inert, stable phosphates. In the initial phase of this study, the lanthanide ions $\mathrm{Nd}^{3+}$ and $\mathrm{Gd}^{3+}$ were used as models for the trivalent actinides $\mathrm{Pu}^{3+}, \mathrm{Am}^{3+}$, and $\mathrm{Cm}^{3+}$. Phytic acid, myo-inositol hexakis(dihydrogenphosphate), was chosen as the organophosphorus complexant. The goal of this part of the project was to determine the bonding in precipitated lanthanide phytates.

Inositol phosphates are the major phosphorus-containing components of cereal grains, and they participate in transport of calcium in cell metabolism. Phytic acid complexes and precipitates divalent and trivalent metal ions, but the solubility of these salts varies with $\mathrm{pH}$ and concentration. ${ }^{1}$ Phytic acid is most readily handled in its completely neutralized (basic) form as the dodecasodium salt hydrate. Two conformations of phytate have been described in the literature: one ( $5 \mathrm{a} / 1 \mathrm{e}$ or axial) has five axial phosphates and one equatorial phosphate around the $\mathrm{C}_{6} \mathrm{H}_{6}$ ring, and the other (5e/1a or equatorial) has equatorial axial phosphates and one axial phosphate around the ring.

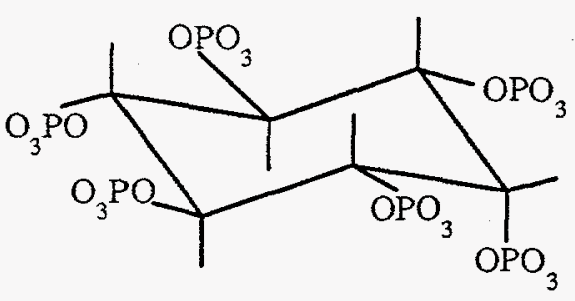

(5e/1a), equatorial

\section{MASTER}

DISTRIBUTION OF THIS DOCUMENT IS UNLIMITED

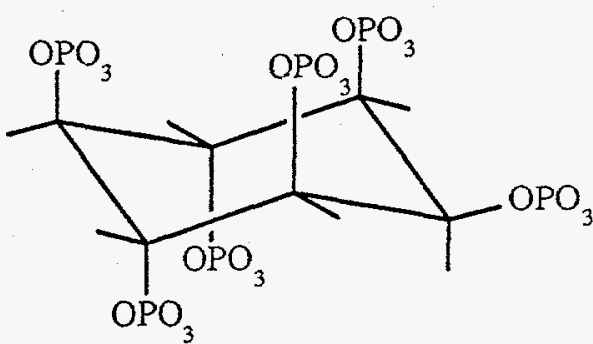

$(5 \mathrm{a} / 1 \mathrm{e})$, axial 
The structure of the hydrate $\mathrm{C}_{6} \mathrm{H}_{6}\left(\mathrm{PO}_{4} \mathrm{Na}_{2}\right)_{6} \cdot 38 \mathrm{H}_{2} \mathrm{O}$ has been determined ${ }^{2}$ to be $(5 \mathrm{a} / \mathrm{le})$. In aqueous solution, ${ }^{13} \mathrm{C}$ and ${ }^{31} \mathrm{P}$ NMR studies have shown ${ }^{3-5}$ that the $(5 \mathrm{e} / 1 \mathrm{a})$ conformation predominates in acid and that the $(5 \mathrm{a} / 1 \mathrm{e})$ predominates in base. Another $31 \mathrm{P}$ NMR study ${ }^{6}$ showed more complex behavior. Since the sodium phytate is a highly basic species, its $(5 \mathrm{a} / \mathrm{le})$ conformation in the solid is consistent with the aqueous species at high $\mathrm{pH}$ characterized by most authors.

Studies of phytic acid-metal ion equilibria and structure models are limited to $\mathrm{Mg}^{2+}$, $\mathrm{Ca}^{2+}$, and some transition metal ions. Martin and Evans found up to $4.8 \mathrm{Ca}^{2+}$ bound to one phytate, with the maximum ratio at $\left.0.006 \mathrm{M}^{2} \mathrm{Ca}^{2+}\right]$ and $0.001 \mathrm{M}$ phytate $^{7}$ and they propose a $6: 1 \mathrm{Ca}^{2+} /$ phytate ratio with the $(5 \mathrm{a} / 1 \mathrm{e})$ conformation:

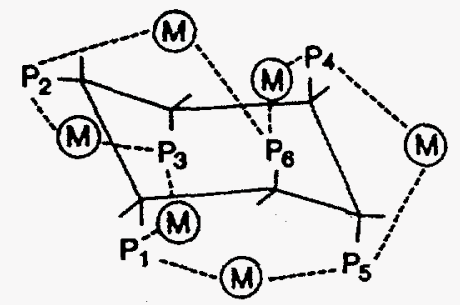

For the $6: 1 \mathrm{Cu}^{2+} /$ phytate species these authors ${ }^{8}$ propose the $(5 \mathrm{e} / 1 \mathrm{a})$ conformation:

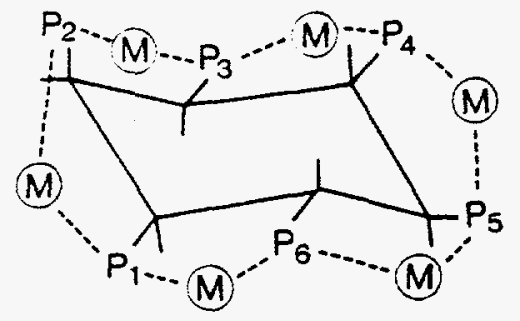

The protonation constants of phytic acid and metal-ligand stability constants for several lanthanide ions with phytic acid in aqueous solution have been determined by potentiometry. ${ }^{9}$ The strongest phytic acid-lanthanide complexes are formed in acid solution, as is normally the case.

The infrared spectrum of phytic acid ${ }^{10}$ has strong absorption bands at $1060 \mathrm{~cm}^{-1}$, which was assigned to $v(\mathrm{P}-\mathrm{O}-\mathrm{C})$ and $1400 \mathrm{~cm}^{-1}$, which was assigned to $v(\mathrm{P}=\mathrm{O})$. Phytin is the neutral mixed $\mathrm{Mg}^{2+} / \mathrm{Ca}^{2+}$ salt of phytic acid. Its infrared spectrum was reported ${ }^{10}$ to show a metal-oxygen vibration at $460 \mathrm{~cm}^{-1}$ and a strong absorption band at $980 \mathrm{~cm}^{-1}$ that is characteristic of the P-O-P bond stretch in pyrophosphate $\left(\mathrm{P}_{2} \mathrm{O}_{7}^{4-}\right)$.

We were not aware of any spectroscopic or crystallographic studies of solid metal phytates other than sodum phytate. Therefore we undertook to prepare solid lanthanide phytates and to characterize their lanthanide coordination by EXAFS. If the bonding in lanthanide phytates is similar to that in lanthanide phosphates, then the phytates should $\mathrm{t}$ : insoluble and should decompose gradually to crystalline and inert phosphates.

\section{SAMPLE PREPARATION AND CHARACTERIZATION}

Crystalline orthophosphates $\mathrm{NdPO}_{4} \cdot \mathrm{xH}_{2} \mathrm{O}$ and $\mathrm{GdPO}_{4} \cdot \mathrm{xH}_{2} \mathrm{O}$ were used as standards. The orthophosphates $\mathrm{NdPO}_{4} \cdot \mathrm{xH}_{2} \mathrm{O}$ and $\mathrm{GdPO}_{4} \cdot \mathrm{xH}_{2} \mathrm{O}$ (Table 1) were precipitated by adding $0.05 \mathrm{M}$ lanthanide nitrate solutions to dilute phosphoric acid solutions, buffered to $\mathrm{pH} 1$ or $\mathrm{pH} 5$ with $\mathrm{NH}_{3}(\mathrm{aq})$. The $\mathrm{pH}$ of the mixtures were readjusted to $\mathrm{pH} 1$ or $\mathrm{pH} 5$ and the mixtures were held at $20^{\circ} \mathrm{C}$ or $50^{\circ} \mathrm{C}$ for three days. The precipitates were separated by 
centrifugation and were dried in air at $100^{\circ} \mathrm{C}$. This temperature is below the temperature of first water loss $\left(200-234^{\circ} \mathrm{C}\right)$ and well below the reported transition temperature of 500$600{ }^{\circ} \mathrm{C}^{11}$ to the anhydrous $\mathrm{LnPO}_{4}$ (monoclinic, monazite). Our X-ray powder diffraction confirmed that the $\mathrm{NdPO}_{4} \cdot \mathrm{xH}_{2} \mathrm{O}$ and $\mathrm{GdPO}_{4} \cdot \mathrm{xH}_{2}$ Ohad the hexagonal structure 11,12 . Mooney did not locate the water molecules but she proposed that there was room for no more than alternate filling of three sites per unit cell with $\mathrm{Z}=3$, i.e. (moles $\left.\mathrm{H}_{2} \mathrm{O}\right) /($ moles $\left.\mathrm{PO}_{4}\right)=\mathrm{x}=0.5$. Other researchers have reported $0<\mathrm{x}<2$. Thermogravimetric analyses of our preparations showed water content $0.5<\mathrm{x}<1$.

To prepare solid phytates, dilute (ca. $0.01 \mathrm{M}$ ) aqueous solutions of $\mathrm{Nd}^{3+}$ and $\mathrm{Gd}^{3+}$ nitrates were reacted with dilute sodium phytate solution at $\mathrm{pH} 3.1-3.2$ in a ratio of 1:1 metal:phytate. Immediate precipitates formed, which were centrifuged, washed with water, recentrifuged, and dried at $95^{\circ} \mathrm{C}$ in air (Table 1). Both $\mathrm{Nd}$ and $\mathrm{Gd}$ phytates were amorphous to $\mathrm{X}$-ray powder diffraction.

Table 1. Samples for EXAFS studies

\begin{tabular}{|c|c|c|c|c|c|}
\hline Description & Preparation & $\begin{array}{c}\text { Structure } \\
\text { (Literature) } \\
\end{array}$ & $\begin{array}{c}\text { Structure } \\
\text { (Found) }\end{array}$ & \multirow{7}{*}{ 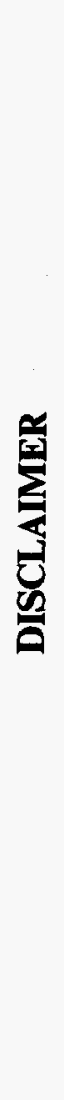 } & 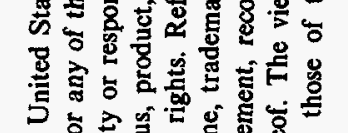 \\
\hline $\mathrm{NdPO}_{4} \cdot \mathrm{xH}_{2} \mathrm{O}$ & $\begin{array}{l}\text { Precipitate at } \\
\mathrm{pH} 5,20^{\circ} \mathrm{C}\end{array}$ & \multirow{6}{*}{$\begin{array}{l}\text { Hexagonal } \\
\text { Hexagonal }\end{array}$} & Hexagonal & & 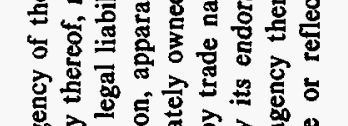 \\
\hline Nd phytate & $\begin{array}{l}\text { Precipitate } 1: 1 \\
\text { ratio at pH } 3.2, \\
\text { dried air } 95^{\circ} \mathrm{C}\end{array}$ & & $\begin{array}{l}\text { Amorphous by } \\
\text { powder X-ray } \\
\text { diffraction }\end{array}$ & & 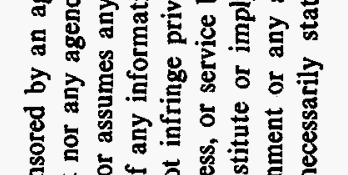 \\
\hline $\begin{array}{c}\text { Nd phytate } \\
\text { (heated, brown) }\end{array}$ & $\begin{array}{l}\text { Precipitate } 1: 1 \\
\text { ratio at } \mathrm{pH} 3.2 \\
\mathrm{TGA} \text { air } 500^{\circ} \mathrm{C}\end{array}$ & & $\begin{array}{l}\text { Amorphous by } \\
\text { powder X-ray } \\
\text { diffraction }\end{array}$ & & 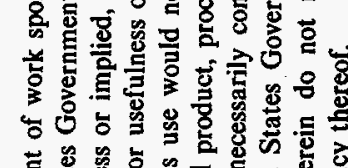 \\
\hline $\mathrm{GdPO}_{4} \cdot \mathrm{xH}_{2} \mathrm{O}$ & $\begin{array}{l}\text { Precipitate at } \\
\text { pH } 5,20^{\circ} \mathrm{C}\end{array}$ & & Hexagonal & & 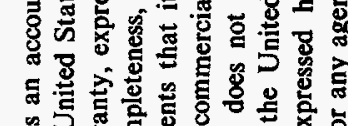 \\
\hline $\mathrm{GdPO}_{4} \cdot \mathrm{xH}_{2} \mathrm{O}$ & $\begin{array}{l}\text { Precipitate at } \\
\mathrm{pH} 5,50^{\circ} \mathrm{C}\end{array}$ & & Hexagonal & & 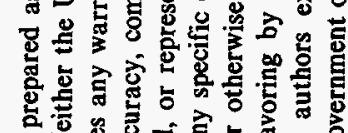 \\
\hline Gd phytate & $\begin{array}{l}\text { Precipitate } 1: 1 \\
\text { ratio at } \mathrm{pH} 3.2, \\
\text { dried air } 95^{\circ} \mathrm{C}\end{array}$ & & $\begin{array}{l}\text { Amorphous by } \\
\text { powder X-ray } \\
\text { diffraction }\end{array}$ & & 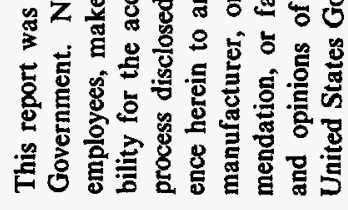 \\
\hline
\end{tabular}

Infrared spectra were taken of all samples (two are shown in Figure 1). The IR spectrum of $\mathrm{NdPO}_{4} \cdot \mathrm{xH}_{2} \mathrm{O}$ is consistent with that reported ${ }^{13}$ : the $\mathrm{PO}_{4}{ }^{3-}$ site symmetry is consistent with $\mathrm{C}_{2}$ symmetry (which is lower than the $\mathrm{D}_{2}$ symmetry required by the space group preferred by Mooney). The IR spectrum of $\mathrm{Nd}$ phytate is rather similar, showing a distinct peak at $990 \mathrm{~cm}^{-1}$ which was seen in calcium-magnesium phytate ${ }^{10}$. 


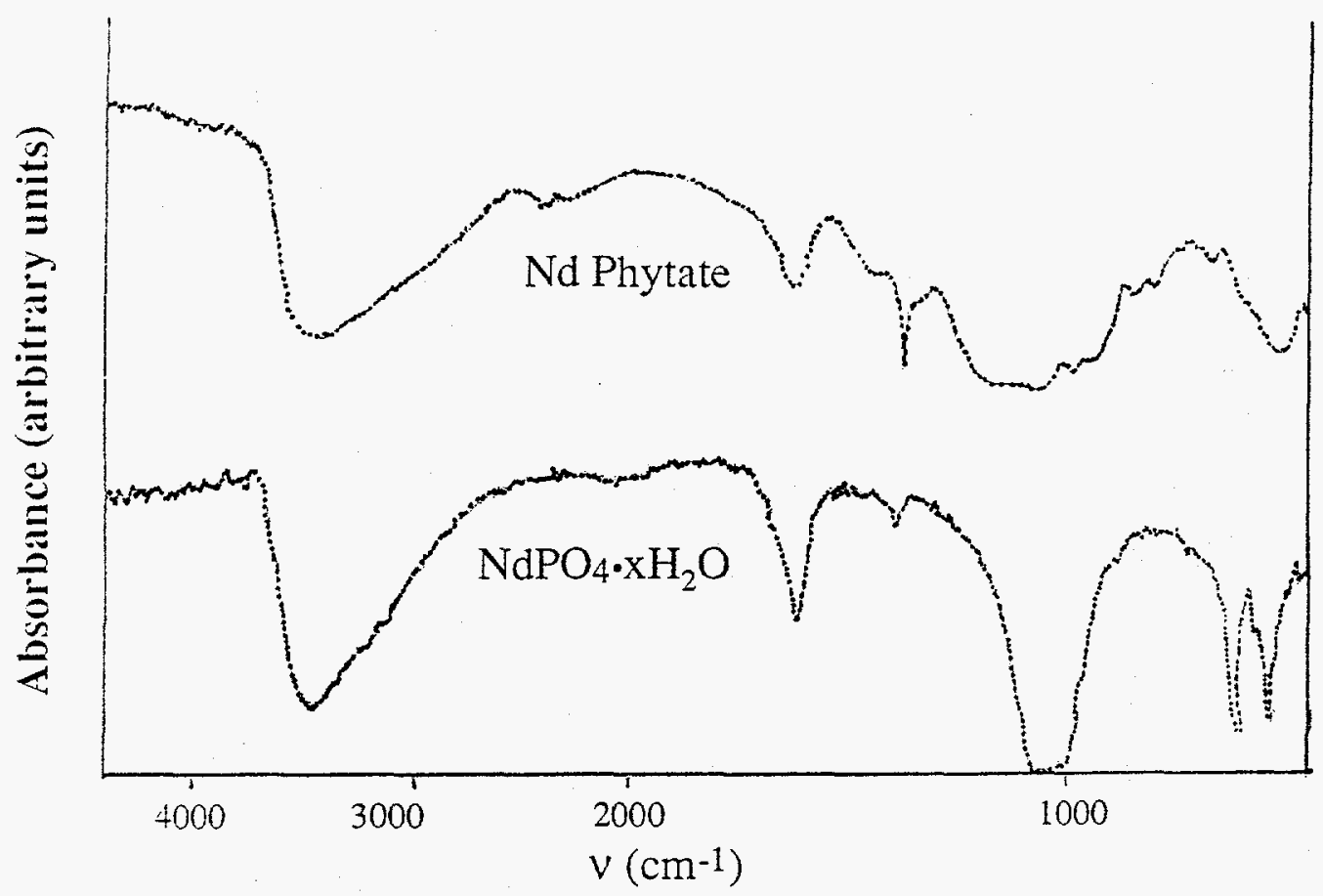

Fig. 1. The infrared spectra of Nd phytate and $\mathrm{NdPO}_{4} \cdot \mathrm{xH}_{2} \mathrm{O}$.

\section{EXAFS DATA ACQUISITION AND ANALYSIS}

Appropriate amounts of phosphates and phytates (Table $\mathrm{I}$ ) were diluted with boron nitride powder in order to give an edge jump of $\sim 1$ across the $\mathrm{Nd}$ and $\mathrm{Gd} \mathrm{L}_{\mathrm{III}}$ absorption edges. The samples were mounted in $1 / 8$ " thick X-ray cells consisting of a polyethylene frame with Kapton windows on each side. All spectra were acquired at room temperature in transmission mode at the Stanford Synchrotron Radiation Laboratory (SSRL) on wiggler beamline 4-1 (unfocused) using a Si(220) double-crystal monochromator. Harmonic rejection was achieved by detuning the monochromator by $50 \%$ relative to the maximum incoming flux measured in $\mathrm{I}_{0}$. The data were calibrated by simultaneously measuring spectra for $\mathrm{Nd}$ and $\mathrm{Gd}$ metal foils, defining the first inflection point of their $\mathrm{L}_{\mathrm{III}}$ edges at 6208 and $7243 \mathrm{eV}$, respectively.

EXAFS data reduction was performed by standard methods using the suite of programs EXAFSPAK developed by G. George of SSRL. ${ }^{14}$ Data reduction included preedge background subtraction followed by spline fitting and normalization (based on the Victoreen falloff) to extract the EXAFS data above the threshold energies, $E_{0}$, defined at 6225 and $7260 \mathrm{eV}$ respectively. Due to the closeness of the $\mathrm{L}_{\mathrm{II}}$ and $\mathrm{L}_{\mathrm{III}}$ absorption edges, the EXAFS data range was limited to $\mathrm{k}=11^{-1} \AA$ for $\mathrm{Nd}$ and $\mathrm{k}=13 \AA^{-1}$ for Gd. Curvefitting analyses were performed using EXAFSPAK to fit then raw $\mathrm{k}^{3}$-weighted EXAFS data. The theoretical EXAFS modeling code, FEFF6, of Rehr et al. ${ }^{15}$ was used to calculate the backscattering phases and amplitudes of the different neighboring atoms which where included in the fits. For FEFF calculations, the atomic parameters for $\mathrm{NdPO}_{4} \cdot \mathrm{xH}_{2} \mathrm{O}$ and $\mathrm{GdPO}_{4} \cdot \mathrm{xH}_{2} \mathrm{O}$ were taken from Mooney. ${ }^{12}$ EXAFS spectra and Fourier transforms are shown in Figures 2 and 3. Bond lengths and coordination numbers are given in Table 2. 


\section{DISCUSSION}

For both phosphate samples, the bond distances and coordination numbers found by EXAFS are in very good agreement with crystallographic values. The neodymium-oxygen distances (2.41 and $2.62 \AA$ ) and coordination numbers (6 and 2$)$ in the Nd phytate samples are similar to those in $\mathrm{NdPO}_{4} \cdot \mathrm{xH}_{2} \mathrm{O}$ (2.41 and $2.58 \AA, \mathrm{CN} 4$ and 4). The same is true for the $\mathrm{Gd}$ samples except that only $7 \mathrm{Gd}-\mathrm{O}$ bonds are seen in $\mathrm{Gd}$ phytate. If each lanthanide is coordinated to oxygens of two adjacent phosphates on a phytate ring, it must be coordinated to an oxygen on another phosphate in the same ring, to a second phytate ring,

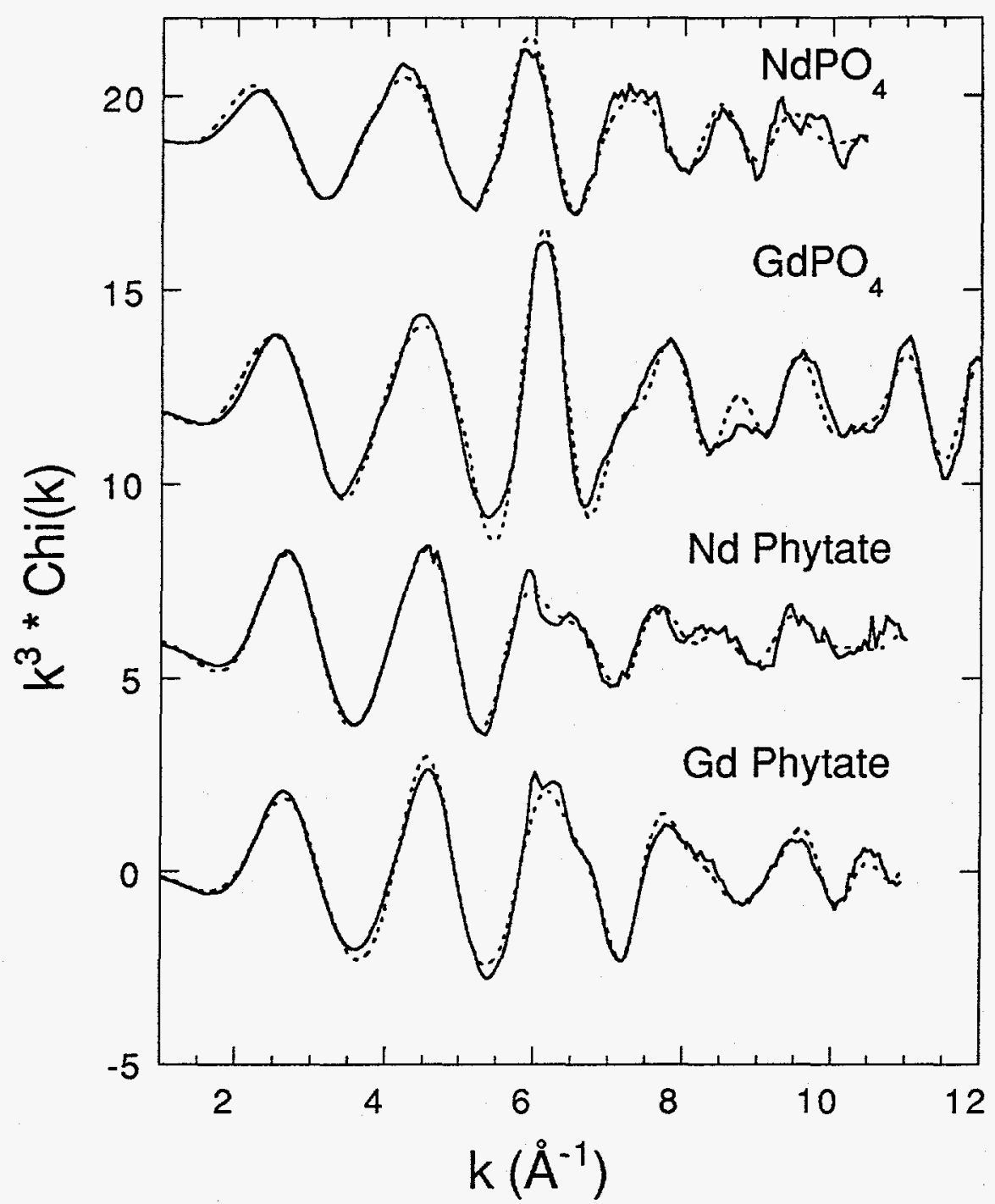

Fig. 2. $k^{3}$ weighted EXAFS spectra at $\mathrm{Nd}$ or Gd LIII edge. Top to bottom: $\mathrm{NdPO}_{4} \cdot \mathrm{xH}_{2} \mathrm{O}$, $\mathrm{GdPO}_{4} \cdot \mathrm{xH}_{2} \mathrm{O}, \mathrm{Nd}$ phytate, Gd phytate. Solid line, experiment; dashed line, fitted.

or to water molecules to complete its coodination sphere. It is worth noting that LnPO $4 \times \mathrm{xH}_{2} \mathrm{O}$ converts upon heating to monazite (monoclinic structure, for $\mathrm{NdPO}_{4}$ nine Nd-O at distances ${ }^{16}$ 2.42-2.76 $\AA$ ); the phytates do not have the monazite coordination geometry.

The shortest Nd-P distances ( $3.20 \AA$ ) in $\mathrm{NdPO}_{4} \cdot \mathrm{xH}_{2} \mathrm{O}$ were found in the $\mathrm{NdPO}_{4} \cdot \mathrm{xH}_{2} \mathrm{O}$ EXAFS but were not found in the Nd phytate; a parallel situation exists for the Gd 
samples. This observation is consistent with the expectation that the metals are bridged between two phosphates, as proposed by Martin and Evans (vide supra), rather than having bidentate (intraligand) metal-phosphate coordination. Three Gd-Gd interactions at $4.59 \AA$ were seen in the Gd phytate. These near neighbors imply that there are four $\mathrm{Gd}^{3+}$ ions bonded on at least some phytate rings in a manner inconsistent with the 1:1 Gd-phytate preparation ratio and inconsistent with the model of Martin and Evans ${ }^{7,8}$ that metal ions bridge adjacent phosphates on the ring. Perhaps some of the phytate has begun to decompose, although our continuing work has shown that lanthanide phytates require two weeks or more at $85^{\circ} \mathrm{C}$ to decompose to crystalline phosphates.

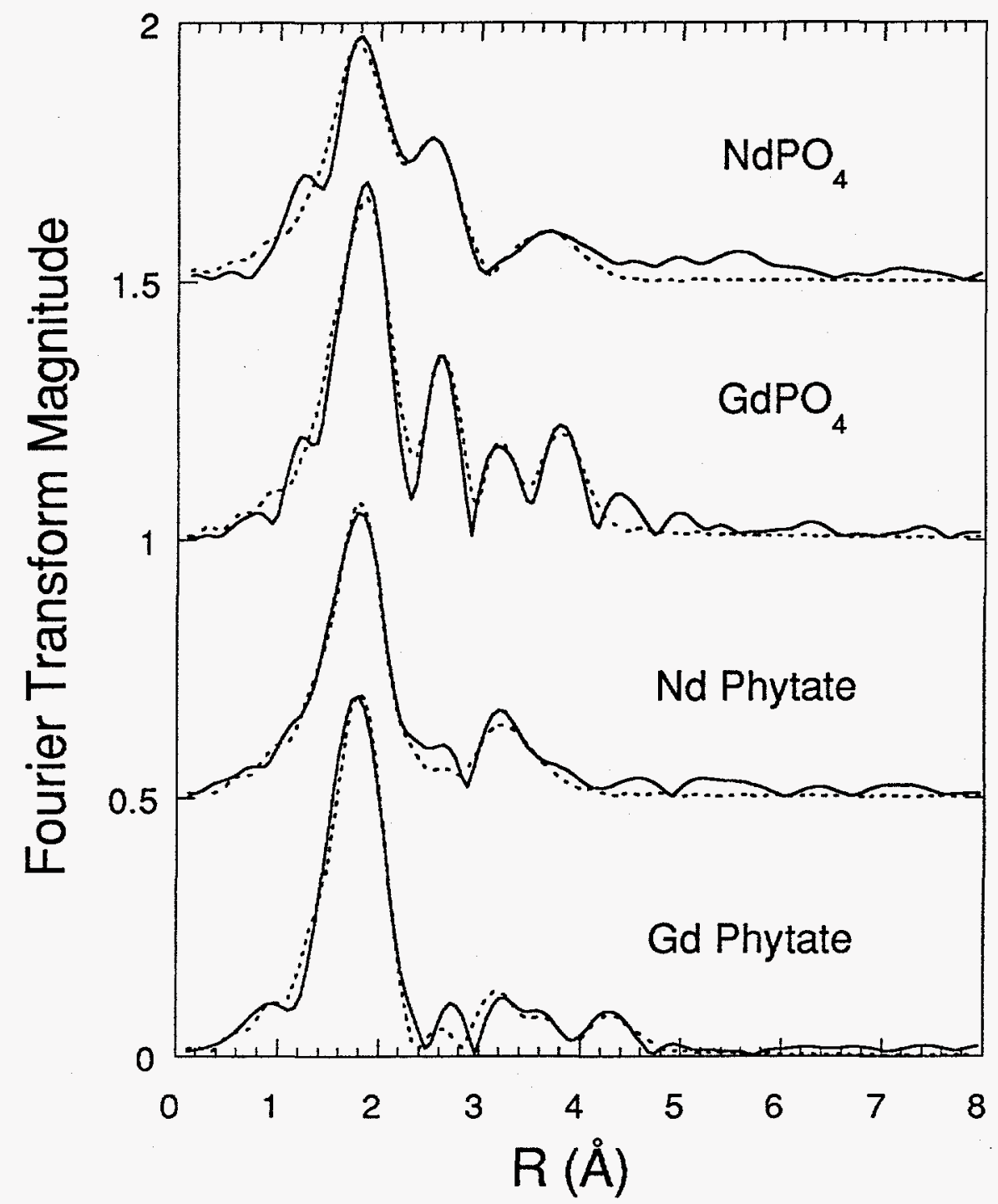

Fig. 3. Fourier transforms of Nd and Gd EXAFS from Fig. 2 (top to bottom, $\mathrm{NdPO}_{4} \cdot \mathrm{xH}_{2} \mathrm{O}$, $\mathrm{GdPO}_{4} \cdot \mathrm{xH}_{2} \mathrm{O}, \mathrm{Nd}$ phytate, $\mathrm{Gd}$ phytate). Solid line, experiment; dashed line, fitted.

There has been one X-ray absorption spectroscopy study ${ }^{17}$ of lanthanide orthophosphates. This was an energy-level study of the $3 d$ levels $3 d_{5 / 2}$ and $3 d_{3 / 2}$ in singlecrystal $\mathrm{LnPO}_{4}$ (monazite or zircon structures) at the $\mathrm{M}_{4,5}$ edge and did not yield EXAFS parameters. Therefore our work appears to be the first EXAFS study of lanthanide 
Table 2. EXAFS Results Compared with Crystallographic (Diffraction) Parameters

\begin{tabular}{|c|c|c|c|c|c|}
\hline \multirow{2}{*}{ Bond } & \multicolumn{3}{|c|}{ EXAFS } & \multicolumn{2}{|c|}{ Diffraction } \\
\hline & $\overline{d(\AA)^{a}}$ & $\mathrm{CN}^{\mathrm{b}}$ & $\overline{\sigma^{2}\left(\AA^{2}\right)^{c}}$ & $\mathrm{~d}(\AA)$ & $\overline{\mathrm{CN}}$ \\
\hline \multicolumn{6}{|c|}{$\overline{\mathrm{NdPO}_{4} \cdot \mathrm{xH}_{2} \mathrm{O}, 20^{\circ} \mathrm{C}}$} \\
\hline $\mathrm{Nd}-\mathrm{O}$ & 2.41 & 4 & 0.0091 & 2.32 & 4 \\
\hline $\mathrm{Nd}-\mathrm{O}$ & 2.58 & 4 & 0.0077 & 2.64 & 4 \\
\hline Nd-P & 3.19 & 2 & 0.0080 & 3.17 & 2 \\
\hline Nd-P & 3.81 & 4 & 0.0183 & 3.65 & 4 \\
\hline $\mathrm{Nd}-\mathrm{Nd}$ & 4.11 & 4 & 0.0175 & 4.11 & 6 \\
\hline \multicolumn{6}{|c|}{$\mathrm{GdPO}_{4} \cdot \mathrm{xH}_{2} \mathrm{O}, 20^{\circ} \mathrm{C}$} \\
\hline Gd-O & 2.39 & 8 & 0.0110 & 2.29 & 4 \\
\hline Gd-O & & & & 2.60 & 4 \\
\hline Gd-P & 3.12 & 2 & 0.0070 & 3.16 & 2 \\
\hline Gd-P & 3.68 & 4 & 0.0125 & 3.60 & 4 \\
\hline $\mathrm{Gd}-\mathrm{Gd}$ & 4.03 & 4 & 0.0123 & 3.93 & 6 \\
\hline \multicolumn{6}{|c|}{$\mathrm{GdPO}_{4} \cdot \times \mathrm{H}_{2} \mathrm{O}, 50^{\circ} \mathrm{C}$} \\
\hline Gd-O & 2.39 & 8 & 0.0115 & 2.29 & 4 \\
\hline Gd-O & & & & 2.60 & 4 \\
\hline Gd-P & 3.12 & 2 & 0.0059 & 3.16 & 2 \\
\hline Gd-P & 3.68 & 4 & 0.0110 & 3.60 & 4 \\
\hline Gd-Gd & 4.03 & 4 & 0.0102 & 3.93 & 6 \\
\hline
\end{tabular}

Nd Phytate

$\begin{array}{llll}\mathrm{Nd}-\mathrm{O} & 2.41 & 6 & 0.0126 \\ \mathrm{Nd}-\mathrm{O} & 2.62 & 2 & 0.0069 \\ \mathrm{Nd}-\mathrm{P} & 3.89 & 2 & 0.0078\end{array}$

Gd Phytate

$\begin{array}{llll}\text { Gd-O } & 2.37 & 7 & 0.0116 \\ \text { Gd-P } & 3.83 & 1 & 0.0028 \\ \text { Gd-Gd } & 4.59 & 3 & 0.0133\end{array}$

a Bond distances

${ }^{b}$ Coordination numbers (for $\mathrm{M}-\mathrm{O}$ ) or nearest neighbors (for $\mathrm{M}-\mathrm{P}$ and $\mathrm{M}-\mathrm{M}$ )

${ }^{c} \sigma=$ Debye-Waller factor

phosphates and indicates that lanthanide $\mathrm{L}_{\mathrm{II}}$-edge spectra are appropriate for obtaining lanthanide coordination environments in phosphates.

We hope to ascertain whether the lanthanide phytates adopt the $(5 e / 1 \mathrm{a})$ conformation found for phytic acid at low $\mathrm{pH}$ by molecular modeling and ${ }^{31} \mathrm{P}$ NMR.

\section{ACKNOWLEDGEMENTS}

Work sponsored by U.S. Department of Energy, at ANL by the Efficient Separations Program, under Contract W-31-109-ENG-38; and at LBNL by the Office of Basic Energy Sciences, Chemical Sciences Division, under Contract DE-AC03-76SF00098.

\section{REFERENCES}

1. E. Graf and J. W. Eaton, J. Nutrition, 114:1192 (1984).

2. G. E. Blank, J. Pletcher, and M. Sax, Acta Cryst., B31:2584 (1975). 
3. L. R. Isbrandt and R. P. Oertel, J. Am. Chem. Soc., 102:3144 (1980).

4. N. Li, O. Wahlberg, I. Puigdomenech, and L.-O. Öhman, Acta Chem. Scand., 43:331 (1993).

5. C. Brigando, J. C. Mossoyan, F. Favier, and D. Benlian, J. Chem. Soc. Dalton:575 (1995).

6. J. Elmsley and S. Niazi, Phosphorus and Sulfur, 10:401 (1981).

7. C. J. Martin and W. J. Evans, J. Inorg. Biochem., 27:17 (1986).

8. C. J. Martin and W. J. Evans, J. Inorg. Biochem., 28:39 (1986).

9. K. S. Siddiqi, S. A. S. Fathi, M. A. M. Aqra, S. Tabassum, S. A. A. Zaidi, and D. Benlian, Indian J. Chem., Sect. A, 32A:421 (1993).

10. K. A. Saburov and K. M. Kamilov, Khimiya Prirodnykh Soedinenii, 6:818 (1990).

11. Y. Hitichi, K.-i. Hukuo, and J. Shiokawa, Bull. Chem. Soc. Japan, 51:3645 (1978).

12. R. C. L. Mooney, Acta Cryst., 3:337 (1950).

13. A. Hezel and S. D. Ross, Spectrochim. Acta, 22:1949 (1966).

14. G. N. George and I. J. Pickering, "EXAFSPAK, A suite of Computer Programs for Analysis of X-ray Absorption Spectra,", Stanford Synchrotron Radiation Laboratory, Stanford, CA, 1995.

15. J. J. Rehr, J. M. d. Leon, S. Zabinsky, and R. C. Albers, Phys. Rev. B, 44:4146 (1991).

16. D. F. Mullica, D. A. Grossie, and L. A. Boatner, J. Solid State Chem., 58:71 (1985).

17. D. K. Shuh, L. J. Terminello, L. A. Boatner, and M. M. Abraham, X-ray absorption spectroscopy of the rare earth orthophosphates, Mat. Res. Soc. Symp. Proc., vol. 307, Boston, MA, 1993, p 95. 